\section{Toothache, Associated Factors, and Its Impact on Oral Health-Related Quality of Life (OHRQoL) in Preschool Children}

Fernanda Ruffo Ortiz ${ }^{1}$, Fernanda Tomazoni' ${ }^{1}$ Marta Dutra Machado Oliveira', Chaiana Piovesann ${ }^{2}$, Fausto Mendes ${ }^{3}$, Thiago M. Ardenghi ${ }^{1}$
'Department of Stomatology, Dental School, UFSM - Federal University of Santa Maria, Santa Maria, RS, Brazil 2UNIFRA - Centro Universitário Franciscano, Santa Maria, RS, Brazil ${ }^{3}$ Department of Pediatric Dentistry, Dental School, USP - University of São Paulo, São Paulo, SP, Brazil

Correspondence: Prof. Thiago Machado Ardenghi, Rua Floriano Peixoto, 1184, 97500-124 Santa Maria, RS, Brasil. Tel: +55-55-3220-9266. e-mail:

thiardenghi@hotmail.com

\begin{abstract}
The aim of this study was to assess the prevalence of toothache, associated factors and impact of this condition on the Child Oral Health Related Quality of Life (COHROoL) in preschoolers. The study was carried out in Santa Maria, Brazil, during the National Children's Vaccination Day, and 534 children aged 0 to 5 years were included. Clinical variables included dental caries and dental trauma. A questionnaire was responded by the parents and provided information about several socioeconomic indicators, dental service use and toothache. Toothache was collected by the question: "Has your child ever had a toothache - Yes or no?". Data on COHRQoL were assessed using the Brazilian version of the Early Childhood Oral Health Impact Scale (ECOHIS). Multivariable Logistic regression models were performed to assess the association between the predictor variables and outcomes. The prevalence of toothache was 10.11\% (95\% Cl: $7.55 \%-12.68 \%)$. Older children had a higher chance of presenting dental pain (OR 2.72;95\% $\mathrm{Cl}: 1.01-7.56$ ), as well as children with caries experience (OR 3.43; 95\% Cl: $1.81-6.52$ ). Moreover, children who had not visited the dental service in the last 6 months were less likely to present toothache (OR $0.51 ; 95 \% \mathrm{Cl}: 0.28-0.95$ ). The presence of dental pain negatively affects the COHRQoL; those with toothache presented a higher chance of having higher impact on the total scores of ECOHIS (OR 4.18; 95\% Cl: 1.76 - 9.95) than those without toothache. Similar observation was found for the child section of the questionnaire (OR 5.54; 95\% Cl: 2.15 - 14.24). Toothache negatively affects COHROoL and is associated with caries experience, age and use of dental service.
\end{abstract}

Key Words: toothache, risk factors, OHROoL.

\section{Introduction}

Dental pain or toothache in children and adolescents has been described as a common experience $(1,2)$ and considered a public health problem $(1,3,4)$. According to the International Association for the Study of Pain (IASP): "Pain is an unpleasant sensory and emotional experience associated with actual or potential tissue damage, or so perceived to harm". Dental pain is described as pain originating from innervated dental tissues or tissues immediately adjacent to the teeth (3).

Most international data on dental pain in children and adolescents have reported period prevalence between 9.1\% and 58\% depending on the case definition and adopted assessment methods (1,5-7). In Brazil, a previous study showed prevalence of dental pain of 16.5\% in 5-year-old children (8). According to the last oral health national survey, the prevalence of dental pain in adolescents aged 12 and 15-19 years-old were 24.6\% and 24.7\% respectively (9). However, there is no national data on the prevalence of dental pain in preschool children in Brazil and population-based studies assessing predictors for toothache in preschoolers are scarce $(7,8,10,11)$.

Knowledge of the associated factors related to dental pain is an important requirement to prevent and manage the occurrence of this condition. Studies have addressed social and demographic determinants and reported strong association of toothache with poor family socioeconomic status $(4,8)$, cumulative episodes of poverty in the life course (2), and dental status such as the presence of dental caries $(8,12,13)$. Conceptual models that link socioeconomic conditions and oral diseases rely on the material deprivation and psychosocial impact of such inequalities on the personal health (14), which leads those from lower socioeconomic groups and less instructed to a worse oral health and consequently to the highest risk for pain (5).

Traditionally, oral health outcomes have been assessed by normative clinical indexes, which measure the patient's health conditions only according to professional judgment, ignoring any social or psychological impacts and placing a relatively low importance on the patient's or parent's self-perceived oral health and needs (15).

Oral health abnormalities have been described as an important feature of well-being that negatively affect children's oral health quality of life (COHROoL) $(1,16)$. Toothache might have a negative impact on a child's emotional status, since it affects sleep patterns and the ability to learn (17). In addition, dental diseases in primary dentition affect not only children's current quality of life 
but also their long-term physical, psychological and social development, as difficult chewing, sleeping, or even an aesthetic discomfort $(1,16)$. Furthermore, dental pain and discomfort have been described as common reasons for seeking dental care (1).

COHROoL is frequently measured by means of selfapplied or filled out by parents questionnaires, also known as socio-dental indicators. Several instruments have been developed to measure oral health and its impact on the quality of life of children and adolescents. The Early Childhood Health Impact Scale (ECOHIS) is one of these instruments (18), and it was adapted and validated to be applied in parents or guardians of children between two and five years old (19). This may contribute to more data on the subject, guiding dental health policies and thereby contributing to the definition and prioritization of the socially appropriate use of resources (19).

Studies assessing the possible predictors for the occurrence of dental pain and its impact on the COHROoL are scarce in preschoolers. Such knowledge may help to tailor public health strategies targeted for population groups with higher levels of need. The aim of this study was to assess the prevalence of toothache, the associated factors and the association of this condition with OHRQoL in 0-5-year-old children from Santa Maria, RS, Brazil.

\section{Material and Methods}

\section{Study Population and Design}

The study was approved by the institutional Research Ethics Committee of the School of Dentistry Centro Universitário Franciscano and parents' consent was obtained prior to the study. A letter was given to all parents explaining the aims of the study and asking them for consent that their children participate in the study. Examiners assured parents that there was not prejudice to the children who would opt to not participate in the study.

A cross-sectional study was conducted in a sample of 0-5-year-old children from Santa Maria, a city in southern Brazil, in August 2013. The city has an estimated population of 261,031 including 18,420 children aged 0 to 5 years.

The following parameters were used for sample size calculation to assess the toothache prevalence: prevalence of toothache of $16.5 \%$ (8), standard error of 5\%, 95\% confidence interval $(\mathrm{Cl})$, a design effect of 1.4 , and $10 \%$ was added to possible refuses. The minimum sample size required was 327 children. To assess the associated factors to the occurrence of toothache, the following parameters were considered: toothache prevalence in the exposed group of 31.3\%, toothache prevalence in the unexposed of 19.3\% (2), 95\% confidence interval (CI), proportion of exposed/unexposed of 1:1, power of the statistical test of $80 \%$ and $10 \%$ was added to possible refuses. The minimum sample size required was 428 children.

\section{Data Collection}

Data were collected through clinical oral examinations and structured interviews by calibrated dentists. The calibration process was performed prior to the survey by a benchmark dental examiner, who had previous experience in epidemiological surveys. Theoretical and clinical training and calibration exercises were arranged for a total of 36 h. For this purpose, a total of 10 children were examined twice by the same examiner with an interval of two weeks between each examination to assess intra and interexaminer reliability.

Participants were randomly selected from children attending the National Children's Vaccination Day Program. This vaccination program has consistently had uptake rates above $97 \%$. Health centers were used as sampling points because the city is administratively divided into five regions, and each one has public health centers that are responsible for the vaccination of the children dwelling in their area. The examiners were assigned to 15 health centers in Santa Maria. The selected points were the largest health centers in the city, and almost $90 \%$ of children visited these centers at the time this study was undertaken. A sampling quota was selected from all children visiting the 15 health centers in the municipality of Santa Maria and the sample was stratified according to the number of children in each area.

During the survey, each fifth child in the queue for vaccination was invited to participate in the study. If their guardians did not consent the participation, the next child in the queue was selected. To avoid selection bias, immediate relatives were excluded. The same selection procedure was used at all 15 participating health centers.

Children were examined while seated on a dental chair under conventional dental illumination, using periodontal probes (CPI; "ball point") and dental mirrors. Clinical examination for recording dental caries (dmf-s) and dental trauma were performed (20). The examination for dental trauma included only anterior teeth.

Data about children's socioeconomic status, use of dental service as well as dental pain were collected through a structured questionnaire. These characteristics were given by parents and guardians. The questionnaire provided information on gender, race, parents' educational level and household income. The survey adopted a classification of the ethnic groups according to the criteria established by the agency for demographic analysis - the Brazilian Institute of Geography and Statistics. Children were classified as "non-white" (black children of African and mixed descent) and "white" (children of European descent).

Educational level compared fathers and mothers that completed 8 years of formal instruction, which in 
Brazil corresponds to primary school, with those that did not. Household income was measured in terms of the Brazilian minimum wage, a standard for this type of assessment, and was dichotomized by the median, which roughly corresponded to US $\$ 740$ during the period of data gathering. The questionnaire also provided information regarding the child's dental visit. The prevalence of dental pain was assessed by the following question: "Has your child ever had a toothache - Yes or no?". The feasibility of the questionnaire was assessed previously in a sample of 10 parents during the calibration process (8).

To assess parent's perception of the COHROoL, the Brazilian version of the Early Childhood Oral Health Impact Scale (ECOHIS) was used ${ }^{19}$. The ECOHIS was specifically developed for use in epidemiological surveys to assess preschool age child OHROoL. It consists of 13 items, including a child impact section (symptoms, function, psychological and self-image/social interaction domains) and a family impact section (parent distress and family function domains). Answers were recorded using a Likert scale with response options scored $0-5(0=$ never; $1=$ hardly ever; 2 = occasionally; $3=$ often; $4=$ very often; $5=$ don't know). Total score had a 0-52 range - the higher the score $\vec{s}$ the greater the impact of oral health problems and related $\Xi$ treatment experiences on OHRQoL of preschool children and their families. Mean ECOHIS scores were calculated for response codes, after recoding all "Don't know" responses as missing. For those with up to two missing responses in the child section or one in the family section, a score for the missing items was imputed as an average of the remaining items for that section (18). No questionnaires were missing more than this maximum and no responses were excluded.

\section{Statistical Analysis}

Data analyses were performed using STATA software 12.0 (Stata Corp., College Station, TX, USA). Descriptive, unadjusted analysis provided summary statistics assessing the association between the outcome (prevalence of dental pain) and explanatory variables. Another analysis was carried out to assess the association between dental pain with the prevalence of severe impacts (percentage of reporting items "often"/"very often") on the ECOHIS total scores and sections.

Multivariable logistic regression models were performed to assess predictors for dental pain as well as to assess the association between dental pain and OHROoL. This strategy allowed estimating the odds ratios among the comparison groups and their respective 95\% confidence interval. Explanatory variables were selected for the final models only if they had a $p$ value $\leq 0.05$ after adjustment.

\section{Results}

A total of 534 children ( $48.3 \%$ girls and $51.7 \%$ boys), were enrolled for the study. The response rate was $90 \%$ of all children invited. Non-participation was mainly if the parents have not signed the term of consent. Table 1 summarizes the distribution of the sample according to demographic characteristics, socioeconomic and clinical status. The mean age of the sample was 2.67 (SD 1.23). Children were predominantly white $(81.2 \%)$; most of their parents presented high educational level and a low household income. The prevalence of dental pain was 10.11\% (95\% Cl: 7.55\% - 12.68\%) and caries experience was $16.4 \%$ (95\% Cl: $13.31 \%$ - 19.53). Only one quarter of the children had visited the dentist (25.05\%).

Table 2 shows results of unadjusted and adjusted analysis for the predictors of dental pain. In the unadjusted analysis, the prevalence of dental pain was associated with age, skin color, use of dental service and caries experience. After the adjustment, the skin color variable lost its significance. Children 4-5 years old had a higher chance to have had tooth pain compared to the younger ones ( $O R$ 2.72; 95\% Cl: 1.01-7.56). The chance of the occurrence of toothache was also higher in children with caries experience (OR 3.43; 95\% Cl 1.81 - 6.52). Those children who had not visited the dental service in the last 6 months were less likely to present toothache (OR $0.51 ; 95 \% \mathrm{Cl} 0.28-0.95$ ).

Total ECOHIS and domain scores are shown in Table 3. Total scores ranged from 0 to 19 with a 1.37 mean (SD = 2.71). The highest mean was for the parent's distress domain (0.36) and the lowest for the child's self-image/social interaction domain (0.04). Two hundred and one mothers $(36.75 \%)$ reported that their children had an impact on at least one ECOHIS item.

Table 4 shows the unadjusted and adjusted logistic regression analyses assessing the association of toothache with the ECOHIS total scores and sections. The presence of dental pain negatively affected the COHROoL; those with toothache presented a higher chance of having higher impact on the total scores of ECOHIS (OR 4.18; 95\% Cl: 1.76 - 9.95) than those without toothache. Analogous observation was performed for the child impact section (OR 5.54; 95\% Cl 2.15 - 14.24).

\section{Discussion}

This is a population-based study that assessed toothache, clinical and sociodemographic associated characteristics, and its impact on oral health related quality of life (COHROoL) of 0-5-year-old children. It was observed that age, use of dental service and caries experience was associated with toothache, which negatively affects children's quality of life.

The study found a $10.1 \%$ prevalence of toothache, a 
value near to that observed in other Brazilian studies with a prevalence of $16.5 \%$ and $9.1 \%$ in this age group $(7,8)$. International studies showed a prevalence of toothache in children and adolescents ranging between $9.1 \%$ and $58 \%$ $(1,6,7,16)$. The low prevalence of toothache in the present study may be explained by the fact that the assessed children participated in the National Child Vaccination Day program and were not looking for dental treatment. Therefore they not necessarily presented some type of oral health problem within the gathered data, which avoided overestimation of the results.

According to this study, toothache was associated with age, use of dental service and caries experience. Yuen et al. (21) also find a higher chance of toothache with the increase of child's age, and this can be explained by the period that primary teeth are exposed in the oral cavity. The association between toothache and use of dental service agrees with a study from the US (6), where children with toothache had a higher chance to seek for dental care. Additionally, $74.9 \%$ of the children in the present study have not visited a dental service in the last 6 months and among those who did, $18 \%$ of the visits were because of dental pain. This shows that parents do not take their children for preventive consultations (6) and suffering leads individuals to seek health services. Mostly, the use of dental care is performed when the child has already some dental problem, mainly toothache. These findings can contribute to the evidence that dental pain, especially in childhood, can be an appropriate and valid indicator for priority setting in oral health care (22).

The association between dental pain and caries experience was also observed in other studies $(8,12,13)$. Such association was expected because dental caries constitutes one of the main determinants of this outcome (3). This ascertainment reveals that dental caries and their severe and cumulative consequences still need more adequate approaches/interventions in order to reduce and/or to control it (13), and these interventions should be implemented in the early stages of life (23). Beyond dental caries, other oral problems such as dental trauma, oral ulcers, tooth eruption and gingivitis may be possible explanations for the occurrence of pain in preschoolers.

This study did not find association of toothache with gender, different from studies performed by Boeira et al. (8) and Nomura et al. (13). Other socioeconomic characteristics as skin color, household income, parent's education and mother's occupation also were not associated with toothache, while other studies found these associations $(2,8,13)$. This may have occurred because the assessed population was almost homogeneous or due to the low prevalence of pain observed, providing a low power to the data analyses. Moreover, a memory bias could haveoccurred
Table 1. Clinical and sociodemographic characteristics of participating children.

\begin{tabular}{|c|c|c|}
\hline Variables & $\mathrm{N}$ & $\%$ \\
\hline \multicolumn{3}{|l|}{ Gender } \\
\hline Female & 263 & 48.26 \\
\hline Male & 282 & 51.74 \\
\hline \multicolumn{3}{|l|}{ Age } \\
\hline$\leq$ 1years-old & 117 & 21.51 \\
\hline 2 to 3 years-old & 252 & 46.32 \\
\hline 4 to 5 years-old & 175 & 32.17 \\
\hline \multicolumn{3}{|l|}{ Skin color } \\
\hline White & 441 & 81.22 \\
\hline Non-white & 102 & 18.78 \\
\hline \multicolumn{3}{|l|}{ Household income } \\
\hline$>2.5 \mathrm{BMW}^{*}$ & 264 & 49.81 \\
\hline$\leq 2.5 \mathrm{BMW}^{*}$ & 266 & 50.19 \\
\hline \multicolumn{3}{|l|}{ Mother's education } \\
\hline$>8$ years & 353 & 65.74 \\
\hline$\leq 8$ years & 184 & 34.26 \\
\hline \multicolumn{3}{|l|}{ Father's education } \\
\hline$>8$ years & 326 & 63.30 \\
\hline$\leq 8$ years & 189 & 36.70 \\
\hline \multicolumn{3}{|l|}{ Mother's occupation } \\
\hline Yes & 314 & 58.36 \\
\hline No & 224 & 41.64 \\
\hline \multicolumn{3}{|l|}{ Toothache } \\
\hline No & 480 & 89.89 \\
\hline Yes & 54 & 10.11 \\
\hline \multicolumn{3}{|l|}{ Last toothache } \\
\hline Less 6 months & 34 & 60.71 \\
\hline 6 months to 1 year & 12 & 21.43 \\
\hline More 1 year & 10 & 17.86 \\
\hline \multicolumn{3}{|l|}{ Caries Experience } \\
\hline $\mathrm{dmfs}=0$ & 458 & 83.58 \\
\hline $\mathrm{dmfs}>0$ & 90 & 16.42 \\
\hline \multicolumn{3}{|l|}{ Dental Trauma } \\
\hline No & 424 & 77.51 \\
\hline Yes & 123 & 22.49 \\
\hline \multicolumn{3}{|l|}{ Household overcrowding } \\
\hline 1 room or more/person & 253 & 46.42 \\
\hline Less than $1 \mathrm{room} /$ person & 292 & 53.58 \\
\hline \multicolumn{3}{|l|}{ Use of dental service } \\
\hline Yes & 135 & 25.05 \\
\hline No & 404 & 74.95 \\
\hline
\end{tabular}

*BMW: Brazilian minimum wage (approximately U\$ 740 during the data gathering). 
Table 2. Frequency distribution, simple and multiple analyses of clinical and socioeconomic variables on the presence of toothache in $0-5$-yearold children

\begin{tabular}{|c|c|c|c|c|}
\hline Variables & $\begin{array}{c}\text { Toothache } \\
\text { n (\%) }\end{array}$ & $\begin{array}{c}\text { No Toothache } \\
n(\%)\end{array}$ & $\begin{array}{l}\text { ORcrude } \\
(95 \% \mathrm{Cl})^{* *}\end{array}$ & $\begin{array}{l}\text { ORadjusted } \\
(95 \% \mathrm{Cl})^{* * *}\end{array}$ \\
\hline \multicolumn{5}{|l|}{ Gender } \\
\hline Female & $31(11.92)$ & 229 (88.08) & 1 & - \\
\hline Male & $23(8.39)$ & $251(91.61)$ & $0.68(0.38-1.19)$ & \\
\hline \multicolumn{5}{|l|}{ Age } \\
\hline$\leq$ 1years-old & $5(4.35)$ & $110(95.65)$ & 1 & 1 \\
\hline 2 to 3 years-old & $20(8.13)$ & $226(91.87)$ & $1.95(0.71-5.32)$ & $1.60(0.57-4.45)$ \\
\hline 4 to 5 years-old & $29(16.86)$ & $143(83.14)$ & $4.46(1.67-11.90)$ & $2.72(1.01-7.56)$ \\
\hline \multicolumn{5}{|l|}{ Skin Color } \\
\hline White & $50(11.63)$ & 380 (88.37) & 1 & 1 \\
\hline Non-White & $4(3.92)$ & $98(96.08)$ & $0.31(0.11-0.88)$ & $0.38(0.13-1.10)$ \\
\hline \multicolumn{5}{|l|}{ Household income } \\
\hline$>2.5 \mathrm{BMW}^{*}$ & $23(9.02)$ & $232(90.98)$ & 1 & - \\
\hline$\leq 2.5 \mathrm{BMW}^{*}$ & $28(10.61)$ & 236 (89.39) & $1.20(0.67-2.14)$ & \\
\hline \multicolumn{5}{|l|}{ Mother's education } \\
\hline$>8$ years & $33(9.59)$ & $311(90.41)$ & 1 & - \\
\hline$\leq 8$ years & $19(10.44)$ & $163(89.56)$ & $1.10(0.60-1.99)$ & \\
\hline \multicolumn{5}{|l|}{ Father's education } \\
\hline$>8$ years & $28(8.81)$ & $290(91.19)$ & 1 & - \\
\hline$\leq 8$ years & $16(8.60)$ & $170(91.40)$ & $0.97(0.51-1.85)$ & \\
\hline \multicolumn{5}{|l|}{ Mother's occupation } \\
\hline Yes & $31(10.16)$ & $274(89.84)$ & 1 & - \\
\hline No & $22(9.91)$ & 200 (90.09) & $0.97(0.55-1.73)$ & \\
\hline \multicolumn{5}{|l|}{ Caries Experience } \\
\hline $\mathrm{dmfs}=0$ & $32(7.14)$ & $416(92.86)$ & 1 & 1 \\
\hline $\mathrm{dmfs}>0$ & $22(25.58)$ & $64(74.42)$ & $4.47(2.44-8.17)$ & $3.43(1.81-6.52)$ \\
\hline \multicolumn{5}{|l|}{ Dental Trauma } \\
\hline No & $39(9.49)$ & $372(90.51)$ & 1 & - \\
\hline Yes & $15(12.20)$ & $108(87.80)$ & $\begin{array}{c}1.32 \\
(0.70-2.49)\end{array}$ & \\
\hline \multicolumn{5}{|l|}{ Household overcrowding } \\
\hline 1 room or more/person & $23(9.16)$ & $228(90.84)$ & 1 & - \\
\hline Less than 1 room/person & $31(10.95)$ & $252(89.05)$ & $1.22(0.69-2.15)$ & \\
\hline \multicolumn{5}{|l|}{ Use of dental service } \\
\hline Yes & $24(18.05)$ & 109 (81.95) & 1 & 1 \\
\hline No & $30(7.59)$ & $365(92.41)$ & $0.37(0.21-0.66)$ & $0.51(0.28-0.95)$ \\
\hline
\end{tabular}


since parents may forget a previous dental pain experience of their children.

The present study found an association of toothache and COHRQoL, corroborating other studies $(1,16)$. Children with toothache showed higher impacts in total and child's session questionnaire, indicating that both child and family quality of life were affected by the child's oral health condition. Toothache is a condition that causes some limitations to these individuals, which has a negative impact on their emotional status, sleep patterns, and ability to learn or perform usual activities, functions essential for child development (17). Additionally, oral diseases and

Table 3. Descriptive distribution of total ECOHIS and domains scores. Santa Maria/Brazil ( $n=547$ mother-child)

\begin{tabular}{|c|c|c|c|}
\hline ECOHIS domains & Mean (SD) & $\begin{array}{c}\text { Possible } \\
\text { range }\end{array}$ & Range \\
\hline \multicolumn{4}{|l|}{ Child section } \\
\hline 1. How often has your child had pain in the teeth, mouth, or jaws? (Symptoms) & $0.23(0.62)$ & $0-4$ & $0-4$ \\
\hline How often has your child...because of dental problems or dental treatments? (Function) & $0.31(0.96)$ & $0-16$ & $0-8$ \\
\hline \multicolumn{4}{|l|}{ 2. Had difficulty drinking hot or cold beverages } \\
\hline \multicolumn{4}{|l|}{ 3. Had difficulty eating some foods } \\
\hline 4. Had difficulty pronouncing any words & & & \\
\hline
\end{tabular}

How often has your child....because of dental problems or dental treatments? (Psychological)

6. Had trouble sleeping

7. Been irritable or frustrated

How often has your child...because of dental problems or dental treatments? (Self-image/social interaction)

8. Avoided smiling or laughing when around other children

9. Avoided talking with other children

Family section

How often have you or another family member...because of your child's dental problems or dental treatments? (Parent distress)

10. Been upset

11. Felt guilty

How often...(Family function)

$0.09(0.43) \quad 0-8 \quad 0-4$

12. Have you or another family member taken time off from work because of your child's dental problems or dental treatments?

13. Has your child had dental problems or dental treatments that had a financial impact on your family?

Table 4. Unadjusted and adjusted assessment of toothache associated with severe scores of ECOHIS-Logistic regression analysis.

\begin{tabular}{lccc} 
& With severe scores* & Without toothache & With toothache OR (95\%Cl)*** \\
\hline ECOHIS (overall scale) & $37(6.76 \%)$ & 1 & $4.18(1.76-9.95)$ \\
Sections & & & \\
Child & $28(5.12 \%)$ & 1 & $5.54(2.15-14.24)$ \\
Family & $13(2.38 \%)$ & 1 & $2.88(0.75-11.04)$ \\
\hline
\end{tabular}

*Number and percentage of reporting items “often” or "very often”. **ogistic Regression Model adjusted by individual level variables: mother's education, dental caries, household income, gender and dental trauma. 
toothache in primary dentition affect the physical status of the children, as well as their psychological well-being and social interactions $(1,16)$. Additionally, parents are also impaired by the occurrence of toothache in their child, since they express feelings of guilt when the child exhibits oral health problems and/or treatment needs (11) and it affects their daily activities (24).

There are some limitations in this study. The crosssectional design does not give the time relationship between the variables, which does not allow determining causality between the predictors and the outcome. In addition, parents reported children's experience of pain by a single question, which may not capture the cumulative prevalence of dental pain during the life course. However, in the data collecting period there was no validated questionnaire to assess toothache in Brazilian children and the first was recently published (25), which must be used in future studies. Despite that, direct questions to the parents is the more commonly used method, since other studies showed that children in this age can underreport dental pain, because of memory bias (24).

One strength of the study is the use of a validated and specific questionnaire to measure OHROoL. The ECOHIS has a reduced number of items, showing that parents can provide valid reports from their preschool children's OHROoL (18). On the other hand, the employed sampling method may be questioned for external validity, because only children who participated of the vaccination program were enrolled. However, as the vaccination program has a wide scope and the selected centers account for nearly $60 \%$ of the children attending the vaccination program, the sample can be considered representative of the preschool children population in Santa Maria.

Despite the limitations, this study offers a relevant perspective for the public health and scientific community through the interactions of toothache, the associated factors and COHROoL, using a representative sample of preschoolers. Therefore, the implementation of oral health policies and oral health promotion in this age group is essential to reduce the prevalence of dental pain and to improve their quality of life.

In conclusion, the results showed that toothache negatively affects $\mathrm{COHROoL}$ and it is associated with caries experience, age and use of dental service. Thus, data of this study justify interventions focused on prevention and reduction of oral diseases.

\section{Resumo}

0 objetivo deste estudo foi avaliar a prevalência de dor dentaria, os fatores associados e seu impacto na qualidade de vida relacionada a saúde bucal de crianças pré-escolares. Esse estudo foi realizado em Santa Maria, Brasil, durante o dia nacional de vacinação infantil, e 534 crianças de 0 a 5 anos foram incluidas. As variáveis clinicas incluidas foram carie dental e traumatismo dentário. Um questionário foi respondido pelos pais, fornecendo informações sobre as condições socioeconômicas, uso de serviços odontológicos e dor dentaria. Dor de dente foi coletada através da pergunta: "Seu filho já teve dor de dente - Sim ou Não?". Os dados sobre qualidade de vida relacionada a saúde bucal foram obtidos através da versão brasileira do questionário "Early Childhood Oral Health Impact Scale" (ECOHIS). Modelos multivariáveis de regressão logistica foram utilizados para avaliar a associação entre as variáveis preditoras e os desfechos. A prevalência de dor dentaria foi 10,11\% (95\% IC: 7,55\% $-12,68 \%)$. Crianças mais velhas apresentaram uma maior chance de ter tido dor dentaria (OR 2,72; 95\% IC: 1,01 - 7,56), assim como crianças com experiência de carie (OR 3,43; 95\% IC: 1,81-6,52). Além disso, as crianças que não tinham visitado o dentista nos últimos 6 meses foram menos propensas a apresentar dor dentária (OR 0,51; 95\% IC: $0,28-0,95)$. A presença de dor dentária afeta negativamente a qualidade de vida relacionada a saúde bucal das crianças; aquelas que tiveram dor de dente apresentaram uma maior chance de ter piores impactos nos escores totais do ECOHIS (OR 4,18; 95\% IC: 1,76 - 9,95) quando comparadas àquelas que não tiveram dor dentária. 0 mesmo se pode observar para a seção do questionário correspondente aos impactos na criança (OR 5,54;95\% IC: $2,15-14,24$. Dor dentaria afeta negativamente a qualidade de vida relacionada a saúde bucal e esta associada com experiência de carie, idade e uso de serviços odontológicos.

\section{References}

1. Mashoto KO, Astrom AN, David J, Masalu JR. Dental pain, oral impacts and perceived need for dental treatment in Tanzanian school students: a cross-sectional study. Health Qual Life Outcomes 2009;7:73.

2. Peres MA, Peres KG, Frias $A C$, Antunes JL. Contextual and individual assessment of dental pain period prevalence in adolescents: a multilevel approach. BMC Oral Health 2010;10:20.

3. Slade GD. Epidemiology of dental pain and dental caries among children and adolescents. Community Dent Health 2001;18:219-227.

4. Barretto EP, Ferreira EF, Pordeus IA. Determinant factors of toothache in 8- and 9-year-old schoolchildren, Belo Horizonte, MG, Brazil. Braz Oral Res 2009;23:124-130.

5. Pau AK, Croucher R, Marcenes W. Prevalence estimates and associated factors for dental pain: a review. Oral Health Prev Dent 2003;1:209220.

6. Lewis C, Stout J. Toothache in US children. Arch Pediatr Adoles Med 2010;164:1059-1063.

7. Oliveira MM, Colares V. The relationship between dental anxiety and dental pain in children aged 18 to 59 months: a study in Recife, Pernambuco State, Brazil. Cad Saude Publica 2009;25:743-750.

8. Boeira GF, Correa MB, Peres KG, Peres MA, Santos IS, Matijasevich A, et al.. Caries is the main cause for dental pain in childhood: findings from a birth cohort. Caries Res 2012;46:488-495.

9. Ministry of Health. SB Brazil Project 2010. Oral health conditions of the Brazilian population 2010 - Main outcomes. Brasilia, DF, 2011.

10. Moure-Leite FR, Ramos-Jorge J, Ramos-Jorge ML, Paiva SM, Vale MP, Pordeus IA. Impact of dental pain on daily living of five-year-old Brazilian preschool children: prevalence and associated factors. Eur Arch Paediatr Dent 2011;12:293-297.

11. Gomes MC, Clementino MA, Pinto-Sarmento TC, Martins CC, GranvilleGarcia AF, Paiva SM. Association between parental guilt and oral health problems in preschool children: a hierarchical approach. BMC Public Health 2014;14:854.

12. Leal SC, Bronkhorst EM, Fan M, Frencken JE. Untreated cavitated dentine lesions: impact on children's quality of life. Caries Res 2012;46:102-106.

13. Nomura LH, Bastos JL, Peres MA. Dental pain prevalence and association with dental caries and socioeconomic status in schoolchildren, Southern Brazil, 2002. Braz Oral Res 2004;18:134-140.

14. Braveman PA, Cubbin C, Egerter S, Chideya S, Marchi KS, Metzler M, et al.. Socioeconomic status in health research: one size does not fit all. JAMA 2005;294:2879-2888.

15. Sheiham A, Tsakos G. Oral Health needs assessments. In: Community Oral Health. Pine C, Harris R (Editors). Mew Malden: Quintessence 
Publishing Co. Limited; 2007. p 59-79.

16. Krisdapong S, Somkotra $\mathrm{T}$, Kueakulpipat W. Disparities in early childhood caries and its impact on oral health-related quality of life of preschool children. Asia Pac J Public Health 2012;26:285-294.

17. Schuch HS, Dos Santos Costa F, Torriani DD, Demarco FF, Goettems ML. Oral health-related quality of life of schoolchildren: impact of clinical and psychosocial variables. Int J Paediatr Dent 2014.

18. Pahel BT, Rozier RG, Slade GD. Parental perceptions of children's oral health: the Early Childhood Oral Health Impact Scale (ECOHIS). Health Qual Life Outcomes 2007;5:6.

19. Martins-Junior PA, Ramos-Jorge J, Paiva SM, Marques LS, Ramos-Jorge ML. Validations of the Brazilian version of the Early Childhood Oral Health Impact Scale (ECOHIS). Cad Saude Publica 2012;28:367-374.

20. World Health Organization WHO. Oral health surveys, basic methods. In. Geneva, 1997:93.

21. Yuen HK, Wiegand RE, Hill EG, Magruder KM, Slate EH, Salinas CF, et al.. Factors associated with toothache among African American adolescents living in rural South Carolina. Soc Work Public Health 2011;26:695-707.
22. de Lacerda JT, de Bem Pereira M, Traebert J. Dental pain in Brazilian schoolchildren: a cross-sectional study. Int J Paediatr Dent 2013;23:131-137.

23. Poulton R, Caspi A, Milne BJ, Thomson WM, Taylor A, Sears MR, et al.. Association between children's experience of socioeconomic disadvantage and adult health: a life-course study. Lancet 2002;360:1640-1645.

24. Ratnayake $N$, Ekanayake L. Prevalence and impact of oral pain in 8-year-old children in Sri Lanka. Int J Paediatr Dent 2005;15:105-112.

25. Daher A, Versloot J, Leles CR, Costa LR. Screening preschool children with toothache: validation of the Brazilian version of the Dental Discomfort Questionnaire. Health Qual Life Outcomes 2014;12:30.

Received January 30, 2014

Accepted November 6, 2014 